\begin{tabular}{|l|l|l|}
\hline \multicolumn{2}{|c|}{ PublisherInfo } \\
\hline \hline PublisherName & $:$ & BioMed Central \\
\hline \hline PublisherLocation & $:$ & London \\
\hline \hline PublisherImprintName & $:$ & BioMed Central \\
\hline \hline
\end{tabular}

\title{
Sequence of a single-celled vulture
}

\begin{tabular}{|l|l|l||}
\hline \multicolumn{2}{|c|}{ ArticleInfo } \\
\hline \hline ArticleID & $:$ & 3785 \\
\hline \hline ArticleDOI & $:$ & $10.1186 /$ gb-spotlight-20001003-02 \\
\hline \hline ArticleCitationID & $:$ & spotlight-20001003-02 \\
\hline \hline ArticleSequenceNumber & $:$ & 222 \\
\hline \hline ArticleCategory & $:$ & Research news \\
\hline ArticleFirstPage & $:$ & 1 \\
\hline \hline ArticleLastPage & $:$ & 2 \\
\hline \hline & $:$ & RegistrationDate : 2000-10-03 \\
ArticleHistory & $:$ & OnlineDate \\
\hline \hline ArticleCopyright & $:$ & BioMed Central Ltd2000-10-03 \\
\hline \hline ArticleGrants & $:$ & \\
\hline \hline ArticleContext & $:$ & 130591111 \\
\hline \hline
\end{tabular}




\section{William Wells}

Email:wells@biotext.com

Thermoplasma acidophilum is an archaeon that lives off the carcasses of organisms that perish in its hot, acidic home. In the 28 September Nature, Ruepp et al. find that the microbe has scavenged genes from its neighbors in order to survive (Nature 2000, 407:508-513). T. acidophilum was originally suspected to be an ancestor of the eukaryotes, as it has complexes involved in protein folding, degradation and turnover that look like simplified versions of the corresponding eukaryotic complexes. But the $1.56 \mathrm{Mbp}$ genome sequence clearly identifies T. acidophilum as an archaeon. Although the microbe's housekeeping genes reflect this phylogenetic origin, many of the genes related to its specialized lifestyle have come from other organisms by lateral transfer. This includes a full $17 \%$ of identified open reading frames that have their closest relatives in Sulfolobus solfataricus, a bacterium that is unrelated genetically but lives in the same extreme environments. Gene transfer may have come more easily to T. acidophilum as it lacks the barriers of either a cell wall or a restriction/modification system.

\section{References}

1. A thermophilic, acidophilic mycoplasma isolated from a coal refuse pile.

2. Phylogenetic structure of the prokaryotic domain: the primary kingdoms.

3. Nature, [http://www.nature.com/nature/]

This PDF file was created after publication. 